\title{
NOTAS
}

\section{John A. Ryan. To be a contemplative in action}

\author{
Alberto Ares Mateos, S. I.
}

Abstract: Spirituality does not come only from books or sermons. It comes from encounters, Jesus met the people and told them stories. John A. Ryan rooted his passion for social and economic justice in the world, in encounter and finding God in all things. A passion that may have made Ryan the first author to combine economic ethics and Church teachings in a way that was uncommon in that period.

The goal of this paper is to present Ryan's thought in our contemporary European context. At the same time, the author will to show how Theology and Social Sciences can walk together in order to clarify the complexity of social processes and incarnate the Kingdom of God in our contemporary world. The paper's author will to show that Ryan's legacy is still able to contribute something constructive to contemporary Church-Culture.

After introducing some brief notes to contextualize his life, this paper describes his main theoretical contributions through two of his most important works, A living Wage and Distributive Justice. Next, the author will show how Ryan tried to incarnate his theories in a social political program that walked hand-in-hand with President Roosevelt's own [New Deal / social development] programs. Third, the paper's author will suggest a few connections between Ryan's main contributions and some contemporary key concepts in Social Sciences and Catholic social teachings.

Key-words: Catholic social teaching, contemplative in action, distributive justice, Kingdom of God, natural law, New Deal, people's capitalism, Ryan.

Fecha de recepción: 10 de octubre de 2015.

Fecha de admisión: 21 de abril de 2016. 


\section{John A. Ryan, ser un contemplativo en la acción}

Resumen: La espiritualidad no reside sólo en libros o en sermones, sino que surge de los encuentros; Jesús se encontró con la gente y les contó historias. John A. Ryan enraizaba su pasión por la justicia social y económica en el mundo en el encuentro y en la búsqueda de Dios en todas las cosas. Esa pasión puede haber hecho que Ryan fuese el primer autor que combinase la ética económica y las enseñanzas sociales de la Iglesia en un proceso inusual para su tiempo.

El objetivo de esta nota es presentar el pensamiento de Ryan en nuestro actual contexto europeoy, al mismo tiempo, mostrar cómo la Teología y las Ciencias Sociales pueden caminar juntas, clarificando la complejidad de los procesos sociales y encarnando el Reino de Dios en nuestro mundo contemporáneo. El autor pretende mostrar que la herencia de Ryan todavía es capaz de contribuir constructivamente a la cultura de la Iglesia contemporánea.

Después de la introducción de algunos breves apuntes para contextualizar su vida, la nota describe las principales contribuciones teóricas por medio de dos de sus trabajos más importantes, A living Wagey Distributive Justice. A continuación, el artículo muestra cómo Ryan trató de encarnar sus teorías en un programa social político que coexistió mano a mano con el propio programa del presidente Roosevelt [el New Deal / desarrollo social]. En tercer lugar, sugiere algunas conexiones entre las contribuciones principales de Ryan y algunos conceptos contemporáneos claves en las ciencias sociales y en la enseñanza social católica.

Palabras clave: Enseñanza social católica, contemplativo en la acción, justicia distributiva, Reino de Dios, New Deal, derecho natural, capitalismo popular, Ryan

\section{John A. Ryan, être un contemplatif dans l'action}

Résumé: La spiritualité ne vient pas seulement des livres ou des sermons. Elle vient de la rencontre, Jésus a rencontré des gens et leur racontait des histoires. John A. Ryan a enraciné sa passion pour la justice sociale et économique dans le monde, dedans de recherche pour trouver Dieu en toute chose. Une passion qui peut avoir fait de Ryan le premier auteur à combiner l'éthique économique et les enseignements de l'Église d'une manière qui était rare dans cette période.

Le but de cet article est de présenter la pensée de Ryan dans notre actuel contexte européen. En même temps, l'auteur veut nous montrer comment la théologie et les sciences sociales peuvent marcher ensemble pour clarifier la complexité des processus sociaux et ainsi incarner le Royaume de Dieu dans le monde contemporain. L'auteur de la note veut montrer que l'héritage de Ryan est encore en mesure de contribuer quelque peu à la construction culturelle de l'Église contemporaine.

Après avoir présenté quelques brefs pointages pour contextualiser la vie de Ryan, le texte décrit ses principales contributions théoriques à travers deux de ses travaux les plus importants, A living Wage (un salaire de vie) et Distributive Justice (Justice distributive). Ensuite, l'auteur montre comment Ryan a essayé d'incarner ses théories dans un programme social politique qui a marché main dans la main avec les propres programmes du président Roosevelt [New Deal / développement social]. Troisièmement, l'auteur propose quelques connexions entre les principales contributions de Ryan et quelques des concepts clés contemporains en sciences sociales et en l'enseignement social catholique.

Mots clé: Enseignement social catholique, contemplative dans l'action, droit naturel, justice distributive, Royaume de Dieu, New Deal, capitalisme populaire, Ryan. 


\section{Life}

John Augustine Ryan was the first of eleven children of an Irish Catholic family. His parents, William and Maria Elizabeth, both Irish immigrants, settled in Vermillion, Minnesota, where John was born. He worked on the family farm and went to school in St. Paul, Minnesota. In 1892 he entered St. Paul Seminary and was ordained in 1898. His family background introduced Ryan in the Populist movement. Through Patrick Ford, the Irish World editor, Ryan read about the abusive power of the corporate trusts.

Ryan then moved to The Catholic University of America where he continued his theological studies and Doctorate in Sacred Theology. Throughout his studies of philosophy, theology and in his spare time during the summers Ryan cultivated his real passion for economics and political science. "My own interest in social and economic subjects was kept up and extended during those four years at the St. Paul Seminary [...]. In the summer vacation of 1894, I read for the first time a manual of economics." ${ }^{\prime 2}$

After thirteen years teaching in St. Paul Seminary, Ryan returned to Washington in 1915 as a Professor of Political Science and Moral Theology in the Catholic University of America. Ryan was also the director of the National Catholic Welfare Council's Social Action Department during its first twenty five years, from 1920 until his death in 1945. In these years, John A. Ryan was among the most well known and influential social action advocates in the Catholic Church.

\section{Social Justice in Action}

In 1897 Ryan read, for the first time, the encyclical Rerum Novarum in which Leo XIII argued from natural law for the absolute right of every citizen to a living wage. This fuelled Ryan's passion for global social and economic justice.

' See Francis L. BRODERICK, Right Reverend New Dealer. John A. Ryan (NY: The McMillan Company, 1963) and John Ryan, Social Doctrine in Action (NY and London: Harper and Brothers Publishers, 1941).

2 John Ryan, Social Doctrine in Action (NY and London: Harper and Brothers Publishers, 1941), 46 See also Francis L. Broderick, Right Reverend New Dealer. John A. Ryan (NY: The McMillan Company, 1963), 21. 
Ryan came to understand the importance of private landownership, but he also realized the inherent limitations present in the rights of private property and the social responsibilities of property. "All titles of property, productivity included, are conventional institutions which reason and experience have shown to be conducive to human welfare. None of them possesses intrinsic or metaphysical validity." ${ }^{3}$

\section{I. A Living Wage ${ }^{4}$}

Ryan was among the first authors to combine economic ethics and Church teaching in a way that was uncommon in that period. In his first main work, Ryan claims that, "the labourer's right to a Living Wage is the specific form of his generic right to obtain, on reasonable conditions, sufficient of the earth's products to afford him a decent livelihood." 5

Kevin Schmiesing suggests that one who wants to understand Ryan's thinking needs to know the three fundamental assumptions that Ryan follows in his application of Catholic social teaching to the Political scene. These three essential assumptions come from three different perspectives: historical, economic and political. The historical assumption is the view that the economic situation of the Middle Ages was better than that since industrialization. The economic assumption is that the classical economists were wrong, and that Hobson was correct about the possibility of overproduction and underconsumption. The third assumption is political - the state represents a safeguard rather than a danger to social progress, freedom and economic well-being. ${ }^{6}$

A living Wage showed the affinity for progressive thinking, although Ryan differed from progressives in the way they followed socialism ideas. Ryan's main objections to socialism, rested on its hypothesis of economic determinism and its antireligious and anti-moral tenets. Ryan doubted the viability of socialist economics, and feared its centralizing propensities. On the other hand, Ryan criticized the Protestant So-

${ }^{3}$ Quoted in John A. Coleman, S. J., "Vision and Praxis in American Theology: Orestes Brownson, John A. Ryan, and John Courtney Murray": Theological Studies 37 (1976), 21.

${ }^{4}$ A Living Wage was Ryan's Ph. D. dissertation.

${ }^{5}$ John RYAN, A Living Wage. Its ethical and economic aspects (NY: The MacMillan Company, 1912), 324.

"Kevin SCHMIESING, "John A. Ryan, Virgil Michel, and the problem of clerical politics", Journal of Church and State (Winter 2003), 113-129. 
cial Gospel movement with W. Rauschenbusch as one of his heads, for failing to sufficiently emphasize that the Church's primary concern is the salvation of souls. "The remarking of the social order was a means to that end, and not the end in itself. [...] He was explicitly critical of his friend Rauschenbusch, who, he felt, went too far in this direction."

In this context, Ryan was always an uncomfortable ally of the political left. As Francis L. Broderick describes:

He did not recognize how closely he approached secular reformers by adopting their vocabulary and symbols. Ryan was always more the progressive than he realized, and more the moral theologian than his progressive friends realized. ${ }^{8}$

One of the most important influences on Ryan's economic thinking was his namesake, John A. Hobson. Ryan was captivated by Hobson's theory of "underconsumption". Hobson argued that if the balance between profits and wages tilted too decisively in favor of profits, capitalists, looking for an outlet of their profits, would increase the oversupply of goods and the workers would lack the money to buy industrial goods, and the demand of goods would come to a standstill. In other words, the gap between supply and demand of goods and services can yield an unsustainable economical system, where profits and wages will diverge and the unemployment rate will increase more and more.

Hobson provides his own liberal-socialist synthesis.

Pure socialism failed to take into account the extent to which human beings had common, quantitative, needs; pure socialism did not fully appreciate human individuality, expressed in 'qualitative' needs. The state's economic boundaries were clear. It should only be concerned with ministering to quantitative needs, which people had in common. Where human needs, capacities and aspirations were different, its jurisdiction should end. Yet people could realise their individuality precisely because the state attended to their common needs. ${ }^{9}$

For Ryan and other progressives, the state had an obligation not only to protect negative rights, but to guarantee the positive ones. The state would be for Ryan more a guarantor of liberty rather than a threat to it.

\footnotetext{
${ }^{7}$ Francis L. Broderick, Right Reverend New Dealer. John A. Ryan (NY: The McMillan Company, 1963), 74.

${ }^{8}$ Francis L. BroderICK, RightReverend New Dealer. John A. Ryan (NY: The McMillan Company, 1963), 153.

9 Jules TownSHEND, J.A. Hobson (Manchester and NY: Manchester University Press, 1990), 99-100.
} 
Ryan presents three central conclusions in his book. First, he thinks that a complete scheme of distributive justice is extremely difficult to formulate. Ryan understands the multifaceted and complex situation of the economical world. Facing this challenge, he proposes specific programs of reform direct toward a distributive justice model in subsequent works. Second, the claim of a universal living wage would mean an enormous improvement in industrial and social conditions. Finally, Ryan thinks that the realization of a universal living wage would be less difficult than the realization of any other alternative plan that would yield equal results. All these issues will be developed in his main work, Distributive Justice.

\subsection{Bishop's Program of Social Reconstruction}

Founded on his interpretation and understanding of Rerum Novarum, and on his widespread study of numerous plans for the reconstruction of post war societies, Ryan authored a program of social reconstruction, issued in 1919 by the National Catholic War Council in the name of the American Bishops. The Bishop's Program became the guiding document for the National Catholic Welfare Council's Social Action Department and for Catholic progressives in the 1920's and 1930's. Many of these recommendations were ratified fifteen years later in the New Deal's programs.

\subsection{Distributive Justice}

In this work, Ryan not only criticised the prevailing situation of land, corporate, wage, etc., but he also proposed a specific program of reforms. Ryan presented a canon of diverse criteria for determining distributive justice and specified priorities to guide decisions in case of conflict.

\subsection{Landownership and Rent}

Ryan found that private landownership had prevailed throughout the world with practical universality from the very beginning. The point of view of Henry George against private ownership of land is invalid according to Ryan's interpretation. George advocated a public land-based fee to be collected by the government, and that all other taxes must be abolished.

It should be emphasized that George did not regard his theory as a mere fiscal reform. He thought of it as a means whereby free enterprise, in which he ardently believed, could be rendered truly free by eliminating a fundamental and pervasive 
monopoly that interferes with the normal operation of the market and diverts a major share of wealth to those who make no positive contribution to the economic process. Rent, he taught, belongs to the community by right, and as long as it is privately appropriated, it serves as a fetter upon production and a barrier to the right of individuals to enjoy the fruits of their toil. Interest, on the other hand, he viewed as the capitalist's just return for that increase in wealth attributable to his saving and investment. If, he held, rent were taken by the public, the speculative element in land prices would disappear, and the consequent cheapness of land would place natural opportunity within the reach of all. Production would be stimulated, wages would rise, the cost of goods would be reduced, and with the extirpation of its basic cause, involuntary poverty would tend to vanish. ${ }^{10}$

\subsubsection{Private landownership: Natural law and natural rights}

For Ryan, the community has no right either to land or to rent. It is the private owner who has a right to both. In fact, Ryan identifies, private landownership ${ }^{11}$ as a natural right ${ }^{12}$, but not in the sense as it is commonly understood. He thinks it is a natural right because it is necessary as a social institution, not because it is connected with individual needs as such.

Ryan distinguishes three classes of natural rights. The first is exemplified in the right to life. Life is the end, immediate and direct in all possible circumstances. The natural rights of the second class are not ends in themselves, but means to human welfare. Among these natural rights belong, "the right to marry, to enjoy personal freedom, and to own consumption-goods." ${ }^{13}$ These rights are directly for, and necessary to the majority of persons. Private ownership of land belongs in the third class of natural rights. These are rights not directly connected with vital ends or needs. "The persons who live reasonable lives without owning land are average

\footnotetext{
10 Robert V. Anderson, "Msgr. John A. Ryan's Critique of Henry George." The American Journal of Economics and Sociology 33, no. 3 (July 1974), 273-86 (emphasis added).

${ }^{11}$ Ryan thinks that first occupancy rather than labor, scarcity or contribution to productivity is the original title to ownership.

12 "Natural rights are the moral means or opportunities by which the individual attains the end appointed to him by nature." John A. Ryan and Francis J. Boland, Catholic Principles of Politics (NY: The MacMillan Company, 1940), 13.

13 John A. Ryan, Distributive Justice, (NY: The MacMillan Company, 1916), 57.
} 
persons." 14 Thus, private ownership it is not directly, but only indirectly necessary for the welfare of the individual. "Private landownership is a natural right because in present conditions the institution is necessary for individual and social welfare." 15

\subsubsection{Single-tax doctrine}

According to Anderson ${ }^{16}$, Ryan describes a series of advantages and disadvantages in his critique of the "single-tax doctrine". The advantages would be: (1) The number of land users would be increased; (2) The land speculator would disappear; (3) Consumers would get goods cheaper; (4) Some stimulus would be given to production and employment; (5) Those monopolies which derive their strength from land would become weaker and tend to disappear.

On the other hand, Anderson describes four disadvantages: (1) Many holdings would deteriorate because of those who would exhaust the land through careless or rapacious exploitation; (2) The administrative machinery would inevitably involve a vast amount of error, inequality, favoritism, and corruption, for the land tax would be on the full amount of the annual rent instead of on a fraction, as at present; (3) Cultivators would not have incentive to make improvements that arise from the hope of selling both improvements and land at a profit, owing to the increased demand for land; (4) The reform would lead to instability of tenure because, owing to misfortunes of various kinds (such as one or two poor crops), many landholders would be temporarily unable to pay the full amount of the rent and would lose their titles.

Ryan has dialogued with complete Socialism and Single Taxers in this part of the book and has concluded that in present conditions, private landownership is preferable to the other two. But this institution is always related to human welfare. "We arrived at the conclusion that private landownership is not unjust, so long as no better system is available." ${ }^{17}$

\footnotetext{
14 John A. Ryan, Distributive Justice, (NY: The MacMillan Company, 1916), 58.

${ }^{15}$ John A. RYAN, Distributive Justice, (NY: The MacMillan Company, 1916), 66.

16 Robert V. Anderson, "Msgr. John A. Ryan's Critique of Henry George." The American Journal of Economics and Sociology 33, no. 3 (July 1974), 273-86.

17 John A. RYan, Distributive Justice, (NY: The MacMillan Company, 1916), 74.
} 
Ryan claims that monopoly, excessive gains and exclusion from the land are in some degree real effects and abuses of the existing system of land tenure. He sums up the proposal of reforming the land system as follows:

Exceptionally valuable lands, as those containing timber, minerals, [...] which are still under public ownership should remain there. Through a judicious system of loans, deserving and efficient persons should be assisted to get possession of some land. Municipalities should lease rather than sell their lands, and should strive to increase their holdings. To take all the future increases in the value of land would be morally lawful, provided that compensation were given to owners who thereby suffered positive losses of interest or principal. To take a small part of the increase, and to transfer very gradually the taxes on improvements and on personal property to land, would probably be just, owing to the beneficial effects upon public welfare. A supertax on large holdings of exceptionally valuable and scarce land would likewise be beneficial and legitimate. ${ }^{18}$

The criterion of social welfare is the only legitimate claim on which a right of private property can be based in Ryan's view. Landowners have a right to a fair rent based on their sacrifice of alternative uses of the land. Nevertheless, their right to rent is inferior to the basic right of their tenants to an honest livelihood. In the case of tension, the latter takes preference.

2.3.4. The Capitalist-interest and Businessman-profits: Ryan's ideal of a sort of people's capitalism based on co-operatives

Ryan discounts the labor theory of value. He thinks that labor produces some things which have no value and other things that have value which is not due to labor. Ryan thinks that utility, scarcity and demand have some moral allegation to contribution to value.

There is a mistake in Socialist thought which says that the laborer has a right to the entire output of industry, and that the capitalist has no right to interest. Ryan concedes to the capitalist a right to interest and to a fair profit, although he distinguishes between small businesses and the large trusts.

Ryan's solution to solve the inequities of the modern industrial system involves a reduction of the sum total of interest and profit. He thought that a system of progressive taxation would be the best solution for the redistribution of the national wealth. $\mathrm{He}$ proposes, two methods of lessening the burden of interest: "a reduction in the rate

18 John A. RYan, Distributive Justice, (NY: The MacMillan Company, 1916), 133. 
of interest, and a wider diffusion of capital through co-operative enterprise." 19 It will be through co-operation that consumers, weaker farmers and merchants do business, obtain goods at lower costs, and save money for investment, while the labourers can slowly become capitalists, interest-receivers, as well as employés and wage-receivers.

All these institutional reforms such as producers' and consumers' co-operatives, credit unions and co-partnership between capital and labor in owning and operating business are the means to a more widely distributing incomes derived from interest and profits. The government is obliged to intervene for the common good in the case of unjust competition in the market against consumers and competitors. And, if necessary, the state should go into competition to tame a monopoly.

\subsubsection{The five canons of distributive justice}

Among Ryan's most important contributions to ethical theory is his five-item canon of distributive justice ${ }^{20}$. Ryan starts with the canon of equality. He thinks that although human beings are equal as moral entities, they are unequal in desires, capacities, and powers. "This canon is unjust because it would treat unequals equally." ${ }^{21}$ In the canon of needs, human needs constitute the primary title to material wealth, and proportional need is a genuine factor in determining distribution. But it not can be the only criteria because it can lead to a "great diminution in the productivity of the more honest, the more energetic, and the more efficient among the agents of production." 22 In the canon of efforts and sacrifice, Ryan thinks that efforts and sacrifice have a just claim upon wealth, but they must be balanced against claims based on need and productivity. According to the canon of productivity, "men should be rewarded in proportion to their contributions to the product." ${ }^{23}$ In the canon of scarcity, the distribution of wealth based on the scarcity-value of one's goods of service is reductively based on reward for sacrifice and the contribution

\footnotetext{
19 John A. RYAN, Distributive Justice, (NY: The MacMillan Company, 1916), 428.

${ }^{20}$ The first three canons are formally ethical, whereas the former two are primarily physical and social.

${ }^{21}$ John A. RYAN, Distributive Justice. The right and wrong of our present distribution of wealth, (NY: The MacMillan Company, 1916): 243.

22 John A. RYAN, Distributive Justice, (NY: The MacMillan Company, 1916), 245.

${ }^{23}$ John A. RYAN, Distributive Justice, (NY: The MacMillan Company, 1916), 247.
} 
of this sacrifice to productivity. "Sheer speculation on the basis of falsely created scarcity, in his opinion, should be outlawed." ${ }^{24}$ Finally, the canon of human welfare summaries the previous ones.

We say 'human' welfare rather than 'social' welfare, in order to make clear the fact that this canon considers the well being of men not only as a social group, but also as individuals. It includes and summaries all that is ethically and socially feasible in the five canons already reviewed. It takes account of equality, inasmuch as it regards all men as persons, as subjects of rights; and of needs, inasmuch as it awards to all the necessary participants in the industrial system at least that amount of remuneration which will meet the elementary demands of decent living and self development. It is governed by efforts and sacrifices, at least in so far as they are reflected in productivity and scarcity; and by productivity and scarcity to whatever extent is necessary in order to produce the maximum net results. It would give to every producer sufficient remuneration to evoke his greatest net contribution to the productive process. ${ }^{25}$

Ryan not only gives us canons of distributive justice, but he also provides priority rules among these canons. Needs have first priority, followed by efforts and sacrifices. Then, productivity takes the next position over scarcity. John Coleman affirms Ryan's stress on the primacy of needs. Long before John Rawls ${ }^{26}$, Ryan was arguing that the industrial system's scheme of distributive justice must be so arranged that it is to the advantage of the least advantaged.

\subsubsection{The duty of distributing superfluous wealth}

Following the Catholic moral tradition, Ryan distinguishes three classes of goods. First are goods necessary to sustain life (necessaries to support existence). "Those utilities which are essential to a healthy and humane existence for a man and his family, regardless of the social position that he may occupy, or the standard of life to which he may been accustomed." 27 Second, goods related to the conventional necessities and comforts, which correspond to the social plane or station in life (necessaries as regards conventional purpose, but superfluous as regards exist-

\footnotetext{
24 John A. Coleman, S.J., "Vision and Praxis in American Theology: Orestes Brownson, John A. Ryan, and John Courtney Murray," Theological Studies 37 (1976): 29.

${ }^{25}$ John A. Ryan, Distributive Justice, (NY: The MacMillan Company, 1916), 252.

${ }^{26}$ It can be enlighten to contrast the economic and ethical analysis of Ryan, with that of John Rawls in A Theory of Justice.

27 John A. Ryan, Distributive Justice, (NY: The MacMillan Company, 1916), 308.
} 
ence). Finally are goods unrelated to support of either existence or social position (superfluous without qualification).

To negotiate in cases of conflict, Ryan provides priority rules. Those who live with the first class of goods do not have obligations in justice to distribute them. On the other hand, the owner of goods in the second class is under obligation to share his goods with those in the first level who have extreme need, but he has no obligation to give his goods for the maintenance of conventional necessities and comforts. As regards the third class of goods, the proportion to be distributed depends upon the volume of need. Ryan says:

If all is needed all must be given. In other words, the entire mass of superfluous wealth is morally subject to the call of grave need. This seems to be the unanimous teaching of the moral theologians. It is also in harmony with the general principles of the moral law that the goods of the earth should be enjoyed by the inhabitants of the earth in proportion to their essential needs. In any rational distribution of common heritage, the claims of health, mind, and morals are surely superior to the demands of luxurious living, or investment, or mere accumulation. ${ }^{28}$

At the first and in the second level, if there is a conflict among the same level then, self-interest can prevail over other-interest. Although Ryan allows some role for self-interest, he carefully circumscribes its limits. For this reason, it is not right to describe Ryan as a utilitarian.

Ryan dialogues with those who think that the distribution of superfluous wealth would deteriorate the economic system since it would take out large sums of capital that could be invested in the market. In his view, the money could be transferred to the investment portfolios of charitable institutions and in this case, no sums of money need be siphoned off the market.

\subsubsection{The labourer and Wages}

Ryan analyzes various theories of fair wages, including "the prevailing rate", "exchange-equivalence" or "productivity", and finds none of them completely in harmony with his principles of justice. The solution, according to Ryan, is a living wage as the minimum of justice and, eventually, complete wage justice through labour organization and legislation. Ryan identifies three methods of increasing wages: a minimum wage by law, labour unions, and co-operative enterprise.

${ }^{28}$ John A. Ryan, Distributive Justice, (NY: The MacMillan Company, 1916), 309-310 
The landowner has a right to all the economic rent, modified by the right of his tenants and employés to a decent livelihood, and by the right of the State to levy taxes which do not substantially lower the value of the land. The capitalist has a right to the prevailing rate of interest, modified by the right of his employés to the 'equitable minimum' of wages. The business man in competitive conditions has a right to all the profits that he can obtain, but corporations possessing a monopoly have no right to unusual gains except those due to unusual efficiency. The labourer has a right to living wages, and to as much more as he can get by competition with the other agents of production and with his fellow labourers. ${ }^{29}$

Toward the end of Distributive Justice Ryan pleads for a considerable change in human hearts and ideals in order to effect just distribution and increased production. He thinks that social reform and spiritual renewal must go hand by hand.

\section{3. "The Right Reverend New Dealer"}

In the 1930's, Ryan saw with enthusiasm both the election of Franklin D. Roosevelt, and the publication of Quadragesimo anno by Pius XI. To his colleagues at Catholic University, the Encyclical was a vindication of Ryan's work ${ }^{30}$. As one can read in his autobiography, Ryan found ample support for his social programs in Quadragesimo anno: "I also derived great comfort from the implicit approval which the Holy Father's pronouncement gave to the socio-ethical doctrines which I had been defending for almost forty years." 31

Ryan became a fervent New Dealer. Indeed, he was given the name "Right Reverend New Dealer" by the radio priest Charles Coughlin. Ryan was a great supporter and defender of FDR's social reforms. In return of his defence, Roosevelt invited Rev. Ryan to give the benediction at two of his inaugurations.

After the Great Depression, Ryan saw the confirmation of his economic theories. Hobson's thesis was correct; excessive production and insufficient consumption caused the Great Depression. The National Recovery Administration attempted to

\footnotetext{
29 John A. RYAN, Distributive Justice, (NY: The MacMillan Company, 1916), 431.

30 "Referring to the new encyclical a few days later, Bishop Shahan, the rector of the Catholic University, observed: 'Well, this is a great vindication for John Ryan'." in John Ryan, Social Doctrine in Action (NY and London: Harper and Brothers Publishers, 1941), 242.

${ }^{31}$ John RyAN, Social Doctrine in Action (NY and London: Harper and Brothers Publishers, 1941), 242.
} 
stabilize capitalism by organizing wages, by regulating output, and by providing some form of worker representation and collective bargaining. Ryan supported efforts to effect minimum wage and child labour legislation. Interestingly, this last position made him powerful enemies within the American Catholic Church.

Ryan spent most of the last fifteen years of his life giving speeches and writing articles, books and commentaries. In 1940, Ryan authored a second social pastoral for the American Catholic bishops on the Church and the Social Order. This document advocated, for other things, for an industrial democracy, with and worker's councils as part of management.

In 1944, in a speech to the Catholic Economic Association, Ryan made a first attempt to apply his principles of social justice to the international economic world. During WWII, Ryan argues that the European's right to US's surplus took preference over US's right to abundance:

Just as the common right of property is morally superior to the precedence, in some situations, over the individual elements; so the common right of mankind to the natural resources of a particular country is sometimes superior to the right of that country's inhabitants. ${ }^{32}$

\section{John A. Ryan: Natural law and political science sa $^{33}$}

\section{I. Influence on Ryan's Methodology}

Ryan's methodology was influenced by a variety of social perspectives; the Irish Populism he experienced during his early days, the progressivism of Richard Ely, the Social Gospel, Neoscholasticism, and the Encyclical Rerum Novarum, with its natural law revival. Although Ryan was influenced by all these movements, he developed a unique point of view on social issues.

${ }^{32}$ Quoted in Francis L. BRODERICK, Right Reverend New Dealer. John A. Ryan (NY: The McMillan Company, 1963), 273-274.

${ }^{33}$ Richard R. GallLARDetz, "John A. Ryan: An Early Revisionist?" Journal of Religious Ethics 18 (Fall 1990), 107-121. 


\subsection{The Methodology of Ryan's Social Ethics}

One of his most significant contributions to the social reform debate was Ryan's application of a philosophy of natural law. Ryan was convinced that natural law provided a middle position between those emphasizing liberty and individualism, and those accentuating equality and collectivism. Natural law theory allows absolute natural human rights that take into consideration human welfare, in terms of both individual and social welfare. Ryan saw natural law as a way to advocate for social reform without falling into the relativism common in progressive movement.

For Ryan itwas a consideration of rational human nature, considered both according to its individual constitution -human dignity-and to its various relations (with others and with God) -natural rights-, which served as criterion for moral judgment. In his proposal for a living wage the next step will be the empirical determination to constitute a just family wage.

\subsection{What were the advantages of this natural law re-interpretation within} rational human nature?

Examining Ryan's interpretation, one can find at least two advantages. The consideration of rational human nature was much less philosophical and therefore better suited to form a broad popular consensus for change. Second, this stress involved a more concrete empirical analysis of human life. "This use of the Social Sciences in the formulation of proximate ethical principles represented one of Ryan's most significant adaptations of the natural law tradition. " ${ }^{34}$ Ryan discerns the essence of Aquinas' method and applies it to his particular context. The fit is not always a good one, and as he worked on the formulation of proximate ethical principles, Ryan was openly critical of some Thomas's positions. An example of this critique is Ryan's study of the justification of slavery in Aquinas. In Ryan's view, Thomas had attempted to apply a general principle without adequately investigating the situation to which it was to be applied.

This critique had an important relevance in his contemporary context. The application of general moral principles had become too complicated within the evident complexity of economic ethics. Ryan thought that to derive proximate principles one needed to know what people actually believed. Ryan recognized that Social

${ }^{34}$ Richard R. GallLardetz, "John A. Ryan: An Early Revisionist?" Journal of Religious Ethics 18 (Fall 1990), 114 
science can help us to understand and articulate this belief. Ryan, like a good social science thinker, is pro in inductive methodology rather than a deductive one.

\subsubsection{Ryan re-worked the natural law tradition in two ways}

Ryan's synthesis of natural law can be described in two mayor statements. First, he derived specific moral principles from a consideration of rational human nature rather than from abstract principles. Second, proximate moral principles must take into account the concrete and complex situation in which human persons are living.

\subsection{Criticism of Ryan's Methodology}

Ryan mainly received two critiques. One came from the "Central-Verein". The German Catholic Central Verein ${ }^{35}$ (CCV) thought that Ryan emphasised symptoms rather than problems. Ryan focused too much on legislative change and state intervention without realizing that the real problem only could be solved if various sectors of the economy were convinced of the importance of real cooperation. "While the CCV never embraced laissez-faire capitalism and was generally critical of the U. S. economic system, it also insisted on the dangers of centralization of economic functions in government, especially at the national level. It was the latter concern that led to disillusionment with the New Deal." ${ }^{\prime 36}$ A second critique came from Virgil Michel, the leader of the liturgical movement. The Catholic Worker movement criticized Ryan for not including the need for spiritual reform in his social reform agenda.

Most of the reforms advocated by the Central-Verein and the Catholic Worker movement have gone largely unrealized, whereas many of Ryan's controversial proposal are now commonplace economic realities (minimum wage laws, targeted government jobs programs, etc.). It is true that Ryan could not combine spiritual insight into pragmatic economic reform. This integration would have to wait until

\footnotetext{
35 The CCV was founded in 1855, with its Central Bureau in St. Louis. The CCV maintained a long tradition of charity and publication on social questions. Besides being absolutely loyal to the teachings of the Church as expressed in papal encyclicals, the CCV was dependent on the legacy of German social thought emanating from Bishop Ketteler and his contemporaries in the late nineteenth century, particularly Heinrich Pesch. In Kevin E. Schmiesing, "Catholic Critics of the New Deal: 'Alternative' Traditions in Catholic Social Thought", Catholic Social Scientist Review, Volume VII, (2002), 6-7

${ }^{36}$ Kevin E. SchmiesING, "Catholic Critics of the New Deal: 'Alternative' Traditions in Catholic Social Thought", Catholic Social Scientist Review, Volume VII, (2002), 7.
} 
Vatican II, and in particular the spirituality of labor offered by John Paul II37. But Ryan, in several parts of his work, pointed the need to attend to spiritual conversion as well as social reform.

The Church is not merely nor mainly a social reform organization, nor is it her primary mission to reorganize society, or to realize the Kingdom of God upon earth. Her primary sphere is the individual soul, her primary object to save souls, that is, to fit them for the Kingdom of God in heaven. [...] Having thus reasserted the obvious truth that the Church's function is the regeneration and improvement of the individual soul with a view to the life beyond, let us inquire how far this includes social teaching or social activity. ${ }^{38}$

\subsection{Conclusion}

Ryan applied the Social Sciences, not as an external source used to compensate for the inadequacies of natural law, but as integral components of an effective natural law philosophy. In this context, Ryan can be understood as a precursor of the later "revisionist debate". This debate involved Josef Fuchs and other Catholic moral theologians who tried to recast the natural law tradition in the light of new insights in both Personalist Philosophy and the Social Sciences.

Ryan also anticipated the "signs of the times" theology in his conviction that Church must enter into public discourse on a much broader range of socio-economic issues and must be unafraid to make concrete proposals, defending them in terms to which all people of good will might assent. ${ }^{39}$

\section{Church and State}

Temptation is always with us. Sometimes one can think that it is better to follow a short cut between Eschatology and Politics, between Theology and History. We have seen throughout history different attempts at influence in the social arena without taking into account ethics. But this was not the case of John Ryan. He developed an economic ethics that anticipated a move from Theology to Politics. Ryan worked to

${ }^{37}$ Mater et Magistra 68-81 and Laborem Exercens 1-27.

${ }^{38}$ John A. RYAN, The Church and Socialism and other essays (Washington, The University Press, 1919), 152-153.

${ }^{39}$ Richard R. Gaillardetz, "John A. Ryan: An Early Revisionist?" Journal of Religious Ethics 18 (Fall 1990), 119. 
integrate Theology and Social science in order to find a better world for individuals and humanity as a whole.

Some have said that Ryan went too far in his alliances with Roosevelt and the New Deal. They describe Ryan as a "secular priest who becomes immersed in the politics of the day, exerting whatever influence he could muster on public policy while providing explication of New Deal reforms in terms acceptable to his Catholic audience." 40 Ryan's ideas did not remain abstract but effected historical change significantly. If one compares Ryan with other Catholic figures in that time, one can see that context is very important in order to act in public life.

An example of these Catholic thinkers was Virgil Michel, the most respected figure in the liturgical reform movement in the US during the 1930's. For a Benedictine monk, who lived in his monastery, it could be easer to maintain his political neutrality at expense of clarity. Although his critiques of American capitalism were radical, Virgil's practical implications would remain hazy. His spiritual regeneration could lead a social change in the long-term, but the society needed a practical reform strongly connected with the prevailing situation. Ryan thought, as it has been noted above, that without a considerable change in human hearts and ideals it would be impossible to face any effective just distribution.

In Ryan's life, the context was crucial. Feeling the needs and listening to the voices of so many people in need, while living in Washington D.C., Ryan as a good apostle of God, was surrounded in the reform programs that would change the course of the US economic policy in that time. He felt that Hobson and Keynes had an economic model that explained not only the Great Depression, but helped to build a new world after WWI. Ryan's proposal for social programs is focused on a distributive justice, where the State is not a threat but a support for liberty and human welfare. Besides this, it was laudable his proposal and research in order to set or fix a reasonable living wage.

How closely can a priest be associated with political figures? Canons 285 and 287 of The Revised Code of Canon Law of 1983 forbid priests to hold positions of temporal power or to take active roles in political parties and labour unions. However, exceptions can be made when political discussions require the assessment of ecclesiastical authority. This exception introduces an ambiguity for some people, but for others it simply recognizes a need in numerous parts of the world.

\footnotetext{
${ }^{40}$ Kevin SCHMIESING, "John A. Ryan, Virgil Michel, and the problem of clerical politics", Journal of Church and State (Winter 2003), 127.
} 
Priests are public figures that make judgements in public. At times there can be confusion about where Catholic doctrine ends and where the priest's begins. In my opinion, this is not sufficient reason to reject any public judgment from a priest. The Code of 1983 would be agreed with this statement within the exception. But, is it lawful to root in one exception a priest's intervention in public life? When one has in mind the medieval popes, how did not think that "power tends to corrupt"? Then, is dangerous for a priest to advocate a political party?

I do not have a clear solution, but I would like to explain the way St. Ignatius of Loyola understands the Principle and foundation 41 from his "Spiritual Exercises". For lgnatius everything was created to serve God our Lord. Thus, human beings may use anything to achieve this end. Basically, everything can be a means to get our end. But becoming indifferent to all things is one of our greatest challenges in life. Then power is not a bad thing for Catholics, but a means to serve God and our fellows. Although power tends to corrupt, one needs to become indifferent to power in order to use it in the right way.

On the other hand, Catholics need to grow in a mature and informed political and social conscience in order to act in the public area. And in order to distinguish which are the Social Catholic Teachings or which private opinions, whether it be a cleric or a lay people talking.

Are there historical limits to Ryan's vision and economic model? For some, Ryan was too sanguine about the possibilities inherent in legislative action, although he saw the inherent contradiction between the spirit of political democracy and industrial autocracy ${ }^{42}$. For others, he remains too much a scholastic Thomist. And, like almost every economist of this period, he has the limitations that later schools of economic thinking could enlighten.

${ }^{41}$ Human beings are created to praise, reverence, and serve God our Lord, and by means of doing this to save theirs soul. The other things on the face of the earth are created for the human beings, to help them in pursuit of the end for which they are created. From this it follows that we ought to use these things to extent that they help us toward our end, and free ourselves from them to the extent that they hinder us from it. To attain this is necessary to make ourselves indifferent to all created things, in regard to everything which is left to our free and is not forbidden. Consequently, on our own part we ought not to seek health rather than sickness, wealth rather than poverty, honor rather than dishonor, a long life rather than a short one, and so on in all other matters. Rather, we ought to desire and choose only that which is more conducive to the end for which we are created. Ignatius OF LOYOLA, Spiritual Exercises, Principle and foundation, n. 23 Translation by George E. Ganss, S.J. (St. Louis: The Institute of Jesuit Sources, 1992), 32.

42 John A. Coleman, S.J., "Vision and Praxis in American Theology: Orestes Brownson, John A. Ryan, and John Courtney Murray," Theological Studies 37 (1976), 33. 


\section{Is Ryan able to say anything constructive into contemporary Church-Culture?}

Drawing on the liberal-socialist synthesis of Hobson and others, Ryan makes his own synthesis follow the thought of social Catholicism as a middle way between individualism and socialism ${ }^{43}$. Although he always refused to accept Socialism as a solution, Ryan emphasised the priority of the common good and the importance of the state as guarantor of liberty.

It increases the actual liberty and opportunity of all those persons who could not or would not exercise the liberty which the law forbids... For instance, child labor legislation increases the opportunities and welfare of children; anti-monopoly laws are calculated to increase the opportunity and welfare of the majority of the population. ${ }^{44}$

For Ryan, Pure socialism did not sufficiently appreciate human individuality and forgot any kind of stimulus to work.

It will be a true and rational conception of the State which will avoid the disadvantages and will gather the advantages of both socialist and individualist models. In addition to this, Ryan presented his proposal of a minimum wage by law, labour unions, and co-operative enterprise. The first two pillars of any social system of a democratic society ${ }^{45}$. Related to the third one, Ryan never saw materialized a successful co-operative movement.

Although Ryan hardly attempted to apply his principles of social justice to the international economic world, his thought is reflected in the motto: "Think Global, Act Local" and all of the glocalization ${ }^{46}$ movement. Ryan used his knowledge of

43 John A. RYAN and Moorhouse F.X. MILLAR, The State and the Church (NY: The MacMillan Company, 1924), 208-233.

${ }^{44}$ John A. RYAn and Moorhouse F.X. Millar, The State and the Church (NY: The MacMillan Company, 1924), 213.

${ }^{45}$ Although "while the universal right to a living wage is not yet actual (thinking in global), the general natural right to a decent livelihood for all workers is valid and should be directive for public policy and private sector policy". David A. KRUEGER, "Can Ryan's economic ethic work for a global economy?" in Religion a public life. The legacy of Monsignor John A. Ryan, ed. Robert G. KENNEDY (NY: University Press of America, 2001), 208.

${ }^{46}$ The concept first appeared in the late 1980s in the Harvard Business Review describing the tempering effects of local conditions on global pressures. The sociologist Roland Robertson -who has popularized the term- describes glocalization as: "the simultaneity - the co-presence - of both universalizing and particularizing tendencies." (1997 Conference "Globalization and Indigenous Culture"). 
natural law, Theology and Political Science to find a means by which the common good and the welfare of everyone could be accounted.

The idea of a co-operative enterprise, from my point of view, can be connected with the phenomenon of collaborative economy ${ }^{47}$ and microcredits ${ }^{48}$ that work to expand an alternative way of development in the world market by "acting local". On the other hand, the importance of family 49 in Ryan's model, through his "living wage", echoes the importance of family for the Catholic tradition ${ }^{50}$.

Ryan also recognizes the local community as source of grace and a condition of possibility that facilitates, "the considerable change in human hearts and ideals" ${ }^{\prime 51}$. This same understanding of the local community was reflected in Roosevelt's public works projects. Ryan emphasized this structure and this change as means to effect a just distribution of wealth. Is this not comparable to communities of hospitality 52 or solidarity with the poor ${ }^{53}$ ? These are communities of Christian inspiration, where a group of people gather together to live as a family, and where those who have special needs are in the center.

\footnotetext{
${ }^{47}$ It is referred to a socio-economic system built around the sharing of talents, goods and services.

48 "Microcredit" is the extension of very small loans to the unemployed, to poor entrepreneurs and to others living in poverty who are not bankable. Muhammed Yunus found Grameen Bank in 1976, the first bank to make loans to poor people in Bangladesh. The success of the Grameen model has inspired similar efforts throughout the world, even among the developing and industrialized nations. 2005 was proclaimed by UNPD the International Year of Microcredit, and in 2006 Grameen Bank and its founder Muhammed Yunus were awarded the Nobel Peace Prize.
}

${ }^{49}$ The origin of the State must be traced back to the family as the original social group from which in turn tribal and village life developed, through kinship and landownership, and resulting gradually in the formation of political society. John A. RYAN and Francis J. BOLAND, Catholic Principles of Politics (NY: The MacMillan Company, 1940), 41.

50 Pope Francis stresses the importance of the family in many of his speeches and writing. The Synod of the family in 2014 reinforces this importance.

${ }^{51}$ John A. RyAN, Distributive Justice (NY: The MacMillan Company, 1916), 432.

52 It is worth quoting the communities of hospitality $(\mathrm{CoHo})$ initiative integrated in the Jesuit Social Sector in Spain, the Spain, the "Welcome" program developed by JRS Europe in France, and other initiatives, for example, Family Promise and Interfaith Hospitality Network in the US.

${ }^{53}$ Patxi Álvarez, Comunidades de Solidaridad (Bilbao: Mensajero, 2002). 
As a summary, I think Ryan's work suggests at least three significant insights that can help us understand/improve our relationship between Church and Culture. First, Ryan has a way of doing advocacy, from a healthy and constructive encounter with the political and economic authorities, from which we can learn much today. Second, his intellectual legacy, straddling two worlds (communism and liberal capitalism), raised new alternatives at the time. His creativity, his way of listening to reality from the needs of the most vulnerable, helped him find creative and consistent solutions, a guide that can help and encourage us to follow his path in our day. Finally, Ryan began many processes and initiatives in his life, some of them successful, but in many others he was only the initiator, the one who planted the seed. His life teaches us that the sower is the Lord, and that historical, social processes require people to open paths and leave in the hands of God and many others the results.

The aim of this article has been to present how Social Sciences and Theology can walk together in order to clarify the social processes' complexity and incarnate the Kingdom of God in our contemporary world. I have shown that Ryan's legacy is still able to present a constructive approach to contemporary Church-Culture. After introducing some brief notes to contextualize his life, I have explained his main theoretical contributions through his two most important works, A living Wage and Distributive Justice. Second, I have shown how Ryan tried to incarnate his theories in a social political program that walked hand-in-hand with Roosevelt's own programs. Next, I have noted how a natural law approach, against some critiques, was crucial in Ryan's methodology in order to integrate theology and Social Sciences. Finally, I have presented connections between Ryan's main contributions and some contemporary key concepts in Social Sciences and Catholic social teachings.

Ryan incarnated in his own life the Ignatian maxima: Finding God in All Things, being contemplative in action. A faith that does justice. The Right Reverend New Dealer lived a passionate life, where encounters with others especially the poor, helped him to root his thirst and desire for social and economic justice in the world. 


\section{Bibliography}

P. Álvarez (2002) Comunidades de Solidaridad, Bilbao, Mensajero.

R. V. Anderson (1974) "Msgr. John A. Ryan's Critique of Henry George": The American Journal of Economics and Sociology 33 (July, 3), 273-86.

A. Ares Mateos (2015) Comunidades de Hospitalidad, Madrid, Jesuitas Social, http://goo.gl/UL9TWS

F. L. Broderick (1963) Right Reverend New Dealer. John A. Ryan, New York, The McMillan Company.

J. A. Coleman (1976) "Vision and Praxis in American Theology: Orestes Brownson, John A. Ryan, and John Courtney Murray," Theological Studies 37, 3-40.

R. R. Gallardetz (1990) "John A. Ryan: An Early Revisionist?": Journal of Religious Ethics 18 (Fall), 107-121.

D. A. KRUeGer (2001) "Can Ryan's economic ethic work for a global economy?" in Religion a public life. The legacy of Monsignor John A. Ryan, ed. Robert G. Kennedy, New York, University Press of America, 197-210.

I. DE LOYOLA (1992) Spiritual Exercises, Principle and foundation, $n^{\circ} 23$ Translation by George E. Ganss, St. Lovis, The Institute of Jesuit Sources.

J. A. Ryan (1912) A Living Wage. Its ethical and economic aspects, New York, The MacMillan Company.

- (1916) Distributive Justice. The right and wrong of our present distribution of wealth, New York, The MacMillan Company.

- (1919) The Church and Socialism and other essays, Washington, The University Press.

- (1941) Social Doctrine in Action, New York and London: Harper and Brothers Publishers.

J. A. Ryan and F. J. Boland (1940) Catholic Principles of Politics, New York, The MacMillan Company. 
J. A. Ryan and M. F. X. Millar (1924) The State and the Church, New York, The MacMillan Company.

K. SCHMIESING (2003) "John A. Ryan, Virgil Michel, and the problem of clerical politics": Journal of Church and State (Winter), 113-129.

K. E. SCHMIESINg (2002) "Catholic Critics of the New Deal: 'Alternative' Traditions in Catholic Social Thought", Catholic Social Scientist Review, 7, 1-23.

J. TownSHEND (1990) J. A. Hobson, Manchester and New York, Manchester University Press.

La Revista de Fomento Social en la red:

\section{www.revistadefomentosocial.es}

En Revista de Fomento Social desde 1997 hemos renovado el interés por dar a conocer al mayor número de personas nuestra producción científica. El acceso es libre desde la aparición de cada número.

Para la "descarga" de los artículos en PDF tan sólo se pide que los lectores se registren previamente por medio de un formulario muy sencillo, que se responde en la propia página informática (website) de la revista y que nos permite conocer quiénes son nuestros lectores.

Los lectores registrados en la web tienen acceso libre a todos los artículos de la Revista de Fomento Social (actualmente están disponibles desde el año 1967).

Además de la posibilidad de "navegar" por los años y números publicados disponibles, la página web incorpora un "buscador" que facilita la localización de toda la información.

A todos los lectores registrados se les envía un correo electrónico con el aviso desde la aparición de cada nuevo número, del que inmediatamente se puede consultar el índice, los resúmenes (abstracts) y palabras clave (key-words) en castellano, inglés y francés, así como el editorial en castellano y en inglés.

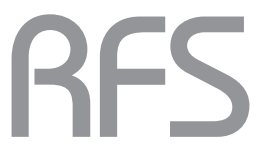

